\title{
Effects of Rock Outcrops On Adjacent Soil Patches And Plants In A Karst Ecosystem In Southwest China
}

You-Xin Shen ( $\square$ yxshen@xtbg.ac.cn )

Xishuangbanna Tropical Botanical Garden,Chinese Academy of Sciences https://orcid.org/0000-00025488-5364

\section{Qing-he Wang}

University of Chinese Academy of Sciences

Zhi-Meng Zhao

Guizhou Education University

Qiong-Fen Li

Stone Forest Scenic Area Administration

Sheng-Chun Bi

Stone Forest Scenic Area Administration

\section{Research Article}

Keywords: karst, rock outcrop, rocky desertification, soil properties, plant biomass

Posted Date: June 22nd, 2021

DOI: https://doi.org/10.21203/rs.3.rs-604404/v1

License: (c) (i) This work is licensed under a Creative Commons Attribution 4.0 International License. Read Full License 


\section{Abstract \\ Purpose}

Rock outcrops (ROCs) are common structures in terrestrial ecosystems, especially in karst regions. However, their effects on adjacent soil patches and plants are rarely studied. In this study, the effects of ROCs on surrounding soils and plants were investigated.

\section{Methods}

Thirty isolated ROCs were randomly selected in a typical semi-humid karst grassland in Southwest China. Rainfall and ROC runoff were collected for chemical analyses. Soil physical and chemical properties and herb above- and belowground biomass were determined at 0 to 30,31 to 60,61 to 90,91 to 190 , and 191 to $290 \mathrm{~cm}$ from the ROC rock-soil interface.

\section{Results}

The $\mathrm{pH}$ and total organic carbon and $\mathrm{Ca}^{2+}$ contents were higher in $\mathrm{ROC}$ runoff than in rainfall. Some soil physical and chemical properties were significantly higher in samples at 0 to $30 \mathrm{~cm}$, and above- and belowground plant biomass were both significantly higher from 0 to $30 \mathrm{~cm}$ and from 31 to $60 \mathrm{~cm}$ than at greater distances. The ROC effect zone, as estimated by logistic equation, was approximately $75 \mathrm{~cm}$. When the area covered by an ROC was between 0.7 and $1.3 \mathrm{~m}^{2}$, herb biomass increased sharply from 0 to $30 \mathrm{~cm}$ and from 31 to $60 \mathrm{~cm}$.

\section{Conclusions}

Karst ROCs affected soils and plants close to their bases, and the effects increased sharply when the area covered by an ROC was of intermediate size.

\section{Introduction}

Rock outcrops (ROCs), either connected to the bedrock or independent, are very common structures associated with patches of soil and plants, especially in karst (Ford and Williams 2013; Waele et al. 2011). The outcrops collect and redistribute precipitation and atmospheric deposition, provide habitat for organisms, and release chemicals after dissolution, among other effects. The surface runoff and the chemicals it contains are then funneled to the rock-soil interface and likely influence adjacent soils and plants. However, the effects of ROCs on soils and plants have received little attention, especially in karst areas. 
Karst ecosystems develop particularly on soluble rocks such as limestone, marble, and gypsum and account for approximately $12-15 \%$ of the ice-free continental area (Ford and Williams 2013). Soils are formed from particles of rock resulting from dissolution processes, and the remaining ROCs give the landscape a "rocky" appearance (Yan et al. 2019). In China, karst land in which ROCs occupy $\geq 30 \%$ of the area and the forest is removed is defined as rocky desertification land. Rocky desertified land accounted for $26.5 \%$ of the total karst area in southern China $\left(120,020 \mathrm{~km}^{2}\right)$ in 2011 (State Forestry of China 2012), which is an enormous challenge when considering ecological restoration. Much effort has been directed to the reconstruction of forests in these lands, but major difficulties have been encountered. Soils and soil-plant relations are key limiting factors that need to be studied (Liu et al. 2020). However, only a few studies have documented differences in soil moisture surrounding ROCs (Li et al. 2014) and water leakage and nutrient loss (Peng et al. 2019). The possible positive effects of ROCs on adjacent soils and plants have rarely been explored.

Rock outcrops collect rainfall in the open, through fall in forests, and dry and wet deposition under different climates. The water and material inputs contribute to the dissolution of rocks (Viles 1995), support the biological activities of microbes and cryptogams dwelling on ROCs (Viles 1995), and even support some vascular communities (Shen et al. 2011; Zhu et al. 2017). The water, materials, and chemicals received and produced on the surface of an ROC are funneled to rock-soil interfaces and redistributed to soil patches (Goransson et al. 2014) or may be leaked from soil to the groundwater system (Liu et al. 2020; Peng et al. 2019). Wang et al. (2016a and 2016b) calculated the percentage of water funneled to the rock-soil interface by measuring rock surface runoff and also compared the chemical contents of runoff and rainfall. Approximate $50 \%$ of the rainfall (through fall in a forest) received by ROCs was redistributed to the rock-soil interface (Wang et al. 2016a), and in the semi-humid climate region of SW China, the runoff was enriched in organic material and nutrients (Wang et al. 2016b). Thus, the important question is whether the runoff from ROCs enriched in nutrients influences adjacent soil patches and soil-plant relations. Unfortunately, this question has not been answered.

Rock fragments (stones $>2 \mathrm{~mm}$ ) on both the surface and in the soil are characteristic of arid and semiarid regions (Tetegan et al. 2015), and they collectively affect soil hydrological processes and chemical transformations (Zhang et al. 2016). Soil erosion and runoff generation decrease when the coverage of rock fragments is from zero to a benchmark percent, after which they decrease (Smets et al. 2011). Rock outcrops in humid and semi-humid areas, such as in karst in SW China, are larger than typical fragments in arid and semiarid zones (Li et al. 2014; Shen et al. 2019). Therefore, they may have larger effects individually and collectively than those of small rock outcrops. In this study, 1) rainfall and ROC runoff were collected and their chemical concentrations determined, and 2) soil properties and plant above- and belowground biomass were determined at different distances from different sized ROCs in a karst site in SW China. The objectives of the study were 1) to analyze the chemicals in ROC runoff that could affect adjacent soil patches; 2) to determine whether soil properties improved in areas close to ROCs; 3 ) to determine whether plant growth increased in areas close to ROCs; and 4) to ultimately evaluate the overall effect of ROCs on soils and plants in karst. 


\section{Materials And Methods}

\section{Study site and selection of rock outcrops}

The study was conducted in a typical semi-humid karst grassland in Shilin County $\left(24^{\circ} 38^{\prime}\right.$ to $24^{\circ} 58^{\prime} \mathrm{N}$, $103^{\circ} 11^{\prime}$ to $103^{\circ} 29^{\prime} \mathrm{E} ; 1,776$ to $1,789 \mathrm{~m}$ a. s. I.), Yunnan Province, Southwest China (Fig. 1a, b). The area climate is subtropical plateau monsoon with a mean annual temperature of $16.2^{\circ} \mathrm{C}$, which fluctuates from a mean maximum of $20.7^{\circ} \mathrm{C}$ (July) to a mean minimum of $8.2^{\circ} \mathrm{C}$ (January). The mean annual rainfall is $967.9 \mathrm{~mm}$, with $80-88 \%$ falling between May and October. The zonal vegetation is semi-humid evergreen broadleaved forest. Because trees and shrubs were removed by human activity, rocky desertification characterizes the study site. The site included perennial herbs, primarily Imperata cylindrica and Heteropogon contortus, as well as annual herbs, such as Arthraxon hispidus. Shrubs and small trees seldom occurred in the area. The karst landforms are primarily composed of Carboniferous, Devonian, and Permian carbonate rocks (Sebela et al. 2004). The soils in the region are shallow, and ROCs rise above the ground along with the surrounding soil patches to form a mosaic structure.

Thirty isolated ROCs were randomly selected. To minimize the possibility of interaction between ROCs, a distance greater than or equal to $6 \mathrm{~m}$ separated them. The coordinates and morphological parameters of each ROC were recorded at the beginning of the dry season. Five sampling areas were established based on their distance to each ROC (Fig. 1C): A, 0 to $30 \mathrm{~cm}$; B, 31 to $60 \mathrm{~cm}$; C, 61 to $90 \mathrm{~cm}$; D, 91 to $190 \mathrm{~cm}$; and $\mathrm{E}, 191$ to $290 \mathrm{~cm}$. Soil physical and chemical properties and aboveground and belowground plant biomass were determined in the areas.

\section{Morphological parameters of rock outcrops}

A self-made profilometer was fixed along the vertical direction of each ROC to measure the surface roughness (Du and $\mathrm{Ge}, 1999$ ). When a contactor of the profilometer moved, a 20 -cm sampling length curve was drawn on a paper. The difference between the highest point of the curve and the reference plane was the roughness value of the sample. Three replicates were taken on the surface of each ROC along horizontal and vertical directions, and their average value was the final roughness value of an ROC. Because there were no significant differences in the roughness of the ROCs $(F=0.162, P<0.01)$, the physical and chemical properties of the ROCs in the study area were assumed to be similar.

A leveling staff was used to measure the height of each ROC, and a gradiometer was used to measure their slopes. A Nikon D7200 digital camera was fixed above a sampling subplot at a height of approximately $3.5 \mathrm{~m}$ to obtain a photograph. A ruler was placed on the ground to provide a reference scale. Then, the coverage area and perimeter of the rocks were calculated using Image $\mathrm{J}$ software.

\section{Rainfall and rock outcrop runoff collection and chemical analyses}


The collection system for ROC runoff water was a PVC plastic frame approximately $1 \mathrm{~m}^{2}$ in coverage and approximately $6 \mathrm{~cm}$ in height that was inserted into grooves cut by cutting machines on the surface of the rocks and fixed with glue, following Wang et al. (2016a). Rock runoff was the water that collected in the frame and drained into a barrel through a plastic pipe. A 22-cm diameter funnel connected to a barrel was placed next to each rock to collect the precipitation received by a ROC. The water in the barrels was collected and measured monthly.

Water samples were collected from ROC runoff and precipitation in June, August, and October 2019. The samples were analyzed for $\mathrm{pH}$ and total $\mathrm{N}(\mathrm{TN})$, total $\mathrm{P}(\mathrm{TP}), \mathrm{K}^{+}, \mathrm{Ca}^{2+}$, and total organic carbon (TOC) concentrations to determine their values at different times in the rainy season. The $\mathrm{pH}$ was measured using a pH meter (FE28, Mettler Toledo, Shanghai, China). Total $\mathrm{N}$ was determined via the alkaline potassium persulfate digestion ultraviolet (UV) spectrophotometric method, and TP was determined using the ammonium molybdate spectrophotometric method. A Shimadzu UV-visible spectrophotometer (UV-2450, Shimadzu Corporation, Tokyo, Japan) was used in the analyses. The $\mathrm{K}^{+}$and $\mathrm{Ca}^{2+}$ concentrations were determined using inductively coupled plasma atomic emission spectroscopy (iCAP 6300, Thermo Electron Corporation, Waltham, MA, USA).

\section{Soil samples at different distances from rock outcrops and their physical and chemical properties}

Six ROCs were randomly selected for soil sampling. Excavations 0 to $30-\mathrm{cm}$ deep were made next to each of the six ROCs, and bulk density was determined with a cutting ring. A soil drill was taken for each sample, and soil was sealed in bags and returned to the laboratory for physical and chemical analyses. The methods described by Danielson and Sutherland (1986) were used to determine soil density, total porosity, initial gravimetric water content, capillary porosity, noncapillary porosity, and capillary holding capacity. The following formulas were used to determine the properties.

Bulkdensity $\left(\mathrm{g} \mathrm{cm}^{-3}\right)=\frac{W_{C R O S}(\mathrm{~g})-W_{C R}(\mathrm{~g})}{100\left(\mathrm{~cm}^{3}\right)}$

Total porosity $(\%)=\left(1-\frac{\text { Bulk density }\left(\mathrm{g} \mathrm{cm}^{-3}\right)}{\text { Soil density }\left(\mathrm{g} \mathrm{cm}^{-3}\right)}\right) \times 100$

Initial gravimetric water content $(\%)=\frac{W_{C R H S}(\mathrm{~g})-W_{C R D S}(\mathrm{~g})}{W_{O R D S}(\mathrm{~g})-W_{C R}(\mathrm{~g})} \times 100$

Capillary porosity $(\%)=\frac{\text { Bulk density }\left(\mathrm{g} \mathrm{cm}^{-3}\right) \times \text { Capillary holding capacity }(\%)}{\rho_{\text {nuatr }}\left(\mathrm{g} \mathrm{cm}^{-3}\right)}$

Noncapillary porosity $(\%)=$ Total porosity $(\%)-$ Capillary porosity $(\%)$ 
Capillaryholding capaticy $(\%)=\frac{W_{\text {WDOSh }}(\mathrm{g})-W_{C R O S}(\mathrm{~g})}{W_{\text {CRDS }}(\mathrm{g})-W_{C R}(\mathrm{~g})} \times 100$

where $W_{C R}(\mathrm{~g})$ is the weight of the cutting ring (inner diameter $50.46 \mathrm{~mm}$; height $50.0 \mathrm{~mm}$; volume 100 $\left.\mathrm{cm}^{3}\right), W_{C R W S}(\mathrm{~g})$ is the weight of the cutting ring filled with natural wet soil, $W_{W D 2 h}(\mathrm{~g})$ is the weight of the cutting ring saturated with distilled water for $24 \mathrm{~h}$ and then drained by gravity for $2 \mathrm{~h}$, and $W_{C R D S}(\mathrm{~g})$ is the weight of the cutting ring oven-dried at $105^{\circ} \mathrm{C}$ for $24 \mathrm{~h}$. To calculate total soil porosity, the particle density of the soil was $2.65 \mathrm{~g} / \mathrm{cm}^{-3}$.

The Biogeochemistry Laboratory at the Xishuangbanna Tropical Botanical Garden measured the soil chemical properties. The soil pH values were measured at 1:5 soil:deionized water. The TOC was measured using the potassium dichromate oxidation heating method, the TN by an elemental analyzer (Vario MAX CN, Elementar Analysensysteme GmbH, Hanau, Germany), and the TP, total potassium (TK), available K (AK), and Ca by inductively coupled plasma atomic emission spectrometry (iCAP 7400, Thermo Fisher Scientific, Waltham, MA, US) after digestion in $\mathrm{HClO}_{4}-\mathrm{HF}$. The available $\mathrm{N}(\mathrm{AN})$ was determined using the alkaline hydrolysis diffusion method, and the available $\mathrm{P}(\mathrm{AP})$ was determined using colorimetric analysis.

\section{Aboveground and belowground plant biomass}

To obtain biomass samples, a $30 \mathrm{~cm} \times 30 \mathrm{~cm}$ frame was used to sample areas $A, B$, and $C$ at each of the 30 ROCs, and a $100 \mathrm{~cm} \times 100 \mathrm{~cm}$ frame was used to sample areas $E$ and F (Fig. 1c). All plants in the framed area were cut and oven-dried at $80^{\circ} \mathrm{C}$ to a constant weight to determine aboveground biomass (AGB). Drills, $6.8 \mathrm{~cm}$ in diameter and $10.0 \mathrm{~cm}$ in height, were collected at three layers: shallow (0 to 10 $\mathrm{cm}$ ), middle (10 to $20 \mathrm{~cm}$ ), and deep (20 to $30 \mathrm{~cm}$ ). Roots were carefully washed and collected on a $0.25-$ $\mathrm{mm}$ sieve. After removal of debris, roots were oven-dried at $80^{\circ} \mathrm{C}$ to a constant weight to determine belowground biomass (BGB). There were three replicates for each layer at the same site.

\section{Statistical analyses}

All data were tested for normality and homogeneity of variances. Paired $t$-tests were used to compare the chemical properties between ROC runoff and rainfall. A one-way ANOVA followed by multiple comparisons was used to test differences between biomass and soil properties among different sampling areas. Correlation analyses were used to test for correlations between the morphological parameters of the ROCs and plant biomass.

Regressions were used to test relations between AGB or BGB and the distance to an ROC. Then, the critical value of the $95 \%$ confidence lower limit of the fitted curve to the lower limit of the function was taken as the maximum distance of the effect of an ROC on biomass (A). Logistic regression was used to 
test relations between $A G B$ or $B G B$ and the coverage area of ROCs. Then, the maximal and average size of an ROC (C) that affected biomass was calculated.

\section{Results}

\section{Chemical concentrations in rainfall and rock outcrop runoff}

The $\mathrm{pH}$ of rainfall was significantly $(P<0.01)$ lower than that of ROC runoff. The concentrations of nutrients in rainfall and runoff were different (Table 1). The concentrations of TOC and $\mathrm{Ca}^{2+}$ in runoff (both greater than $10 \mathrm{mg} / \mathrm{L}$ ) were significantly higher than those in rainfall, but the concentration of $\mathrm{K}^{+}$in runoff (ca. $0.196 \mathrm{mg} / \mathrm{L}$ ) was significantly lower. Concentrations of $\mathrm{N}$ and $\mathrm{P}$ in runoff were not significantly compared with those in rainfall.

Table 1

$\mathrm{pH}$ and nutrient concentrations (mg/L) in rainfall and rock outcrop (ROC) runoff in Shilin karst, SW China

\begin{tabular}{|lll|}
\hline & Rainfall & ROC runoff \\
\hline $\mathrm{pH}$ & $6.31 \pm 0.13 \mathrm{~b}$ & $6.68 \pm 0.11 \mathrm{a}$ \\
\hline TOC & $7.36 \pm 0.73 \mathrm{~b}$ & $11.77 \pm 1.29 \mathrm{a}$ \\
\hline TN & $1.203 \pm 0.25 \mathrm{a}$ & $1.179 \pm 0.24 \mathrm{a}$ \\
\hline TP & $0.142 \pm 0.02 \mathrm{a}$ & $0.124 \pm 0.01 \mathrm{a}$ \\
\hline $\mathrm{K}^{+}$ & $0.503 \pm 0.137 \mathrm{a}$ & $0.196 \pm 0.100 \mathrm{~b}$ \\
$\mathrm{Ca}^{2+}$ & $4.586 \pm 1.549 \mathrm{~b}$ & $10.765 \pm 1.356 \mathrm{a}$ \\
\hline
\end{tabular}

Note: Different lowercase letters within a row indicate a significant difference at $P<0.01$ (paired $t$ test).

\section{Soil physical and chemical properties with distance from rock outcrops}

Soil physical and chemical properties were significantly different between sampling areas $A$ ( 0 to $30 \mathrm{~cm})$ and B (31 to $60 \mathrm{~cm}$ ) (Tables 2 and 3 ). The initial soil moisture, total porosity, and non-capillary porosity were significantly higher in sampling area $A$ than in the other sampling areas $(P<0.05$, Table 2$)$. The results were similar for the soil TOC, TN, AN, and $\mathrm{Ca}$, with contents higher in sample area $\mathrm{A}$ than in the other sample areas (Table 3 ). Soil $\mathrm{pH}$ decreased significantly from sampling area $A$ to sampling area $B$ and from sampling area $B$ to sampling area $C(P<0.05)$. Soil capillary porosity, TP, AP, TK, and AK were not significantly different among sampling areas. 
Table 2

Soil physical properties at different distances from the base of rock outcrops

\begin{tabular}{|c|c|c|c|c|c|}
\hline Sampling area & A & B & C & D & $E$ \\
\hline Bulk density $\left(\mathrm{g} \mathrm{cm}^{-3}\right)$ & $\begin{array}{l}1.24 \pm 0.03 \\
b\end{array}$ & $\begin{array}{l}1.36 \pm 0.02 \\
a\end{array}$ & $\begin{array}{l}1.37 \pm 0.02 \\
a\end{array}$ & $\begin{array}{l}1.37 \pm 0.01 \\
a\end{array}$ & $\begin{array}{l}1.38 \pm 0.01 \\
a\end{array}$ \\
\hline $\begin{array}{l}\text { Initial gravimetric water } \\
\text { content (\%) }\end{array}$ & $\begin{array}{l}19.07 \pm \\
1.28 \mathrm{a}\end{array}$ & $\begin{array}{l}9.27 \pm 1.44 \\
b\end{array}$ & $\begin{array}{l}9.12 \pm 1.51 \\
b\end{array}$ & $\begin{array}{l}9.31 \pm 1.37 \\
b\end{array}$ & $\begin{array}{l}9.25 \pm 1.43 \\
b\end{array}$ \\
\hline Total porosity (\%) & $\begin{array}{l}52.65 \pm \\
0.71 \mathrm{a}\end{array}$ & $\begin{array}{l}48.17 \pm \\
0.39 \mathrm{~b}\end{array}$ & $\begin{array}{l}48.26 \pm \\
0.57 \mathrm{~b}\end{array}$ & $\begin{array}{l}48.09 \pm \\
0.36 \mathrm{~b}\end{array}$ & $\begin{array}{l}48.13 \pm \\
0.42 \mathrm{~b}\end{array}$ \\
\hline Capillary porosity (\%) & $\begin{array}{l}44.34 \pm \\
0.77 \mathrm{a}\end{array}$ & $\begin{array}{l}45.16 \pm \\
0.74 \mathrm{a}\end{array}$ & $\begin{array}{l}45.21 \pm \\
0.71 \mathrm{a}\end{array}$ & $\begin{array}{l}45.10 \pm \\
0.85 \mathrm{a}\end{array}$ & $\begin{array}{l}45.02 \pm \\
0.93 a\end{array}$ \\
\hline Non-capillary porosity (\%) & $\begin{array}{l}8.31 \pm 1.09 \\
a\end{array}$ & $\begin{array}{l}3.01 \pm 0.81 \\
b\end{array}$ & $\begin{array}{l}3.05 \pm 0.87 \\
b\end{array}$ & $2.99 \pm 0.72$ & $\begin{array}{l}3.11 \pm 0.93 \\
b\end{array}$ \\
\hline
\end{tabular}

Note: Values are the mean \pm standard error $(n=6)$. Distances of sampling areas from the base of rock outcrops: A, 0 to $30 \mathrm{~cm}$;, 31 to $60 \mathrm{~cm}$, C, 61 to $90 \mathrm{~cm}$; , 91 to $190 \mathrm{~cm} ; \mathrm{E}, 191$ to $290 \mathrm{~cm}$. Different lowercase letters in a row indicate a significant difference at $P<0.05$ (one-way ANOVA).

Table 3

Soil chemical properties at different distances from the base of rock outcrops

\begin{tabular}{|c|c|c|c|c|c|}
\hline $\begin{array}{l}\text { Sampling } \\
\text { area }\end{array}$ & A & B & C & D & E \\
\hline $\mathrm{pH}$ & $6.84 \pm 0.07 \mathrm{a}$ & $6.55 \pm 0.05 b$ & $6.44 \pm 0.05 c$ & $6.36 \pm 0.06 c$ & $6.37 \pm 0.08 c$ \\
\hline TOC (g/kg) & $24.58 \pm 0.05 a$ & $20.76 \pm 8.40 b$ & $19.10 \pm 6.26 b$ & $17.74 \pm 6.91 b$ & $18.36 \pm 8.08 b$ \\
\hline $\mathrm{TN}(\mathrm{g} / \mathrm{kg})$ & $1.53 \pm 0.55 \mathrm{a}$ & $1.23 \pm 0.31 b$ & $1.12 \pm 0.19 b$ & $1.05 \pm 0.18 b$ & $1.177 \pm 0.39 b$ \\
\hline AN (g/kg) & $0.18 \pm 0.05 a$ & $0.15 \pm 0.04 b$ & $0.14 \pm 0.04 b$ & $0.13 \pm 0.04 b$ & $0.14 \pm 0.04 b$ \\
\hline TP $(\mathrm{g} / \mathrm{kg})$ & $0.71 \pm 0.09 a$ & $0.67 \pm 0.08 \mathrm{a}$ & $0.68 \pm 0.04 a$ & $0.65 \pm 0.04 a$ & $0.66 \pm 0.09 a$ \\
\hline AP (mg/kg) & $0.52 \pm 0.34 \mathrm{a}$ & $0.51 \pm 0.22 \mathrm{a}$ & $0.47 \pm 0.22 \mathrm{a}$ & $0.40 \pm 0.18 \mathrm{a}$ & $0.52 \pm 0.38 \mathrm{a}$ \\
\hline TK (g/kg) & $4.61 \pm 0.46 \mathrm{a}$ & $4.68 \pm 0.69 a$ & $4.72 \pm 0.61 \mathrm{a}$ & $4.78 \pm 0.48 \mathrm{a}$ & $4.72 \pm 0.39 a$ \\
\hline AK (mg/kg) & $\begin{array}{l}114.92 \pm \\
25.63 \mathrm{a}\end{array}$ & $\begin{array}{l}116.16 \pm \\
26.08 \mathrm{a}\end{array}$ & $\begin{array}{l}109.91 \pm \\
10.91 \mathrm{a}\end{array}$ & $\begin{array}{l}118.75 \pm \\
30.26 \mathrm{a}\end{array}$ & $\begin{array}{l}106.40 \pm \\
35.77 \mathrm{a}\end{array}$ \\
\hline $\mathrm{Ca}(\mathrm{g} / \mathrm{kg})$ & $4.99 \pm 1.49 a$ & $4.02 \pm 0.53 b$ & $3.96 \pm 0.39 b$ & $3.65 \pm 0.58 b$ & $3.55 \pm 0.71 b$ \\
\hline
\end{tabular}

\section{Biomass with distance from rock outcrops}


Both AGB and BGB were significantly different among different sampling areas $(F=56.04, P<0.01)$. All values decreased with increasing distance from the ROCs before stabilizing (Fig. 2). However, for both $A G B$ and $B G B$, significant differences were only detected between sampling areas $A$ and $B$ and between sampling areas $\mathrm{B}$ and $\mathrm{C}(P<0.05)$. A four-parameter logistic curve described the relation of biomass with distance (Fig. 2). Then, the lower $95 \%$ confidence limit of the fitted curve to the lower limit of the function was used as the maximum distance of the effect of an ROC, which was approximately $75 \mathrm{~cm}$ for both $A G B$ and $B G B$.

\section{Correlations between rock outcrop characteristics and plant biomass}

The coverage area, perimeter, and height of the ROCs were correlated with the biomass of sampling areas $\mathrm{A}$ and $\mathrm{B}$ and the total biomass $(P<0.05$, Fig. 3 ). However, these morphological parameters were weakly correlated with the biomass of sampling areas $C, D$, and $E$. In addition, the slope and roughness of the ROCs were weakly correlated with biomass. The highest degree of correlation was between the coverage area of the ROCs and biomass ( $r=0.87$ for AGB, $r=0.85$ for BGB, $P<0.05$ ), and therefore, the coverage area was used an indicator to represent the size of the ROCs indetermining the relation between biomass and ROC.

There was little change in $A G B$ and $B G B$ in sampling areas $A$ and $B$ with an increase in ROC size when the ROC was smaller than approximately $0.7 \mathrm{~m}^{2}$ (Fig. 4). However, biomass then increased sharply as ROC size increased to approximately $1.3 \mathrm{~m}^{2}$. Further increases in ROC size had little effect on biomass. The relations between $A G B$ and $B G B$ in sampling areas $A$ and $B$ and the coverage area of the ROCs were described by a four-parameter logistic curve $(P<0.05)$ :

AGB in area $A$ and coverage area: $y=0.442+(0.264-0.442) /\left[1+(x / 0.896)^{\wedge} 6.25\right]$

AGB in area $B$ and coverage area: $y=0.374+(0.243-0.374) /\left[1+(x / 1.092)^{\wedge} 21.56\right]$

$B G B$ in area $A$ and coverage area: $y=0.657+(0.391-0.657) /\left[1+(x / 0.906)^{\wedge} 5.72\right]$

BGB in area $B$ and coverage area: $y=0.547+(0.358-0.547) /\left[1+(x / 1.056)^{\wedge} 17.23\right]$

\section{Discussion}

Rock outcrops are very common morphological structures in terrestrial ecosystems that affect surrounding soil patches and plant growth, especially in karst. However, few studies have examined the effects of ROCs on soils and plants or soil-plant relations. In this study, ROC runoff was chemically enriched compared with rainfall, and soil physical and chemical properties and grass AGB and BGB were higher in samples closer to ROCs than in those at greater distances. Thus, ROCs influenced soils and plant growth, as well as soil-plant relations, within a certain range of the karst rock-soil interface. 
The effects of rock fragments (> $2 \mathrm{~mm}$ ) on soil hydrological processes (e.g., erosion, infiltration, runoff generation, solute transport, and water flow) are a hot topic among soil scientists, especially in arid and semiarid areas (see review by Zhang et al. 2016). Although karst ROCs have received only limited attention (Li et al. 2014; Peng et al. 2019), they are now being studied because of the recent environmental problems associated with karst, such as the rocky desertification in SW China (Jiang et al. 2014; Waele et al. 2011). Rock outcrops in karst in SW China are larger than typical fragments (Li et al. 2014; Shen et al. 2019). They capture enormous amounts of rainfall (through fall in forests) in humid and semi-humid areas and then funnel and redistribute the water to adjacent soil patches (Wang et al. 2016a; Wang et al. 2016b). In this study, the ROC runoff water contained higher nutrient concentrations than those in rainfall (Table 1). When water and nutrients reach the rock-soil interface, they either diffuse into soil (Li et al. 2014) or leak via the rock-soil interface (Zhao et al. 2018) (ignoring losses to evaporation) and thus affect nearby soils and plants. In this study, some soil physical and chemical properties in the area 0 to $30 \mathrm{~cm}$ from an ROC were higher than those in areas farther than $30 \mathrm{~cm}$ (Tables 2 and 3), demonstrating the effects of ROCs on soil properties. However, the distances diffused by water and chemicals in soil are limited by the chemical characteristics (Goransson et al. 2014). Distance from an ROC did not significantly affect $P$ and $K$ concentrations (Table 3 ). Rock outcrops also significantly affected plant $A G B$ and BGB, as indicated by the decrease in biomass beyond $60 \mathrm{~cm}$ from an ROC (Fig. 2).

The range and strength of ROC effects are controlled by many factors. Equations were used to determine the following two important parameters: 1) $75 \mathrm{~cm}$ was the maximum distance of the effect of an ROC on plant biomass (both aboveground and belowground) (Fig. 2); and 2) when the area covered by an ROC was between $0.7 \mathrm{~m}^{2}$ and $1.3 \mathrm{~m}^{2}$ (Fig. 4), biomass increased sharply, but when the coverage was less than $0.7 \mathrm{~m}^{2}$ or greater than $1.3 \mathrm{~m}^{2}$, an increase in coverage did not affect biomass. Thus, $75 \mathrm{~cm}$ was the maximum distance of water and nutrient diffusion in the study site. Rock outcrops less than $0.7 \mathrm{~m}^{2}$ in coverage did not collect and generate sufficient water and nutrients to influence the surrounding soil. When ROCs were greater than $1.3 \mathrm{~m}^{2}$ in coverage, the water and nutrients funneled and redistributed diffused to more surrounding areas within the diffusion maximum of $75 \mathrm{~cm}$. This study is the first to use these values to describe the effects of ROCs.

Collectively, the effects of ROCs are complex. The concept of marginal effect was introduced early in ecology (Friedmann and Beecher 1942). This effect is found in the transitional zone between different landscape types, patch shapes, and study organisms and can be indicated by the structure of the biological community, biodiversity, productivity, and even the behavior of organisms (Friedmann and Beecher 1942; Vanak et al. 2010; Wang and Ma 1985). The effects of ROC as indicated by soil properties and plant biomass in adjacent soil patches are also a type of marginal effect. The small range (maximum $75 \mathrm{~cm}$ ) is significant in comparison with other "ecological marginal effects". Rock outcrops in karst as a group have large effects on soil-plant interactions and thereby affect ecosystem processes. In China, karst land with ROC coverage greater than $30 \%$ and with the forest removed is defined as being affected by rocky desertification. In 2011, 120,020 km² was defined as rocky desertified land, accounting 
for $26.5 \%$ of the total karst area in southern China (State Forestry of China 2012). In those lands, ROCs are numerous, and because each one may have different coverage, the range of effects will differ in surrounding areas. If the land surface is put on a map and the ranges are colored, the effect range of individual ROCs may be circular, resulting in many "effect circles" on the map. The higher the percentage of ROCs is, the greater the amount of colored soil area. When the shape of ROCs, e.g., circular or polygonal, and other factors that influence the effect range are considered, as well as the elements under ROC influence, the "effect circles" will be complex and diverse. The map will need different colors to show different strengths or elements for an effect. If the effects on soils and plants are mapped together, the colorful map might identify the diverse plant-soil interactions affected by ROCs. The multiple effects of ROCs can contribute to the heterogeneity of soil patches and plant diversity in karst (Clements et al. 2006).

Karst ecosystems account for approximately $12-15 \%$ of ice-free continental areas and are an important type of terrestrial ecosystem (Ford and Williams 2007). Differences in rainfall patterns, carbonate content, and climate determine the size of ROCs as well as the runoff and the diffusion of runoff water and chemicals. Thus, the effects of ROCs, including both the range and type and concentration of chemicals, can vary greatly. Further studies are needed to fill the gaps in understanding. Vegetation restoration in rocky desertified karst areas has been very difficult in China, raising alarms. To improve restoration practices, the findings of this study suggest that planting seedlings close to ROCs (approximately 0 to 75 $\mathrm{cm}$ ) can increase survival and growth by obtaining additional water and nutrient inputs from ROC runoff.

\section{Conclusion}

Rock outcrops are widespread surface features in terrestrial ecosystems. They have various edge effects on the karst plant matrix via the export of water and nutrients in runoff. In this study, ROCs improved nearby soil physical and chemical properties and consequently increased plant growth. The effect zone as quantified by plant biomass had an approximate width of $75 \mathrm{~cm}$ and was primarily regulated by coverage area and other morphological characteristics of ROCs. When coverage of an ROC was between $0.7 \mathrm{~m}^{2}$ and $1.3 \mathrm{~m}^{2}$, plant biomass adjacent to an ROC increased sharply. These results indicate a strong edge effect of ROCs, which could be used to support ecological restoration. Future studies of the edge effect at small scales in rocky desertification areas are also needed.

\section{Declarations}

\section{Funding}

The National Natural Science Foundation of China (41671031), the Chinese Academy of Sciences 135 Program (2017XTBG-F01), and the National Key Research and Development Program of China (2016YFC0502503) supported this work. 


\section{Conflicts of interest/Competing interests}

The authors declare that they have no competing interests.

\section{Availability of data and material}

The data sets used during the study are available from the corresponding author on reasonable request.

\section{Code availability}

Not applicable

\section{Authors' contributions}

Qinghe Wang designed the experiment, collected and analyzed the data, and wrote the manuscript. Youxin Shen acquired the funding, supervised the project, and reviewed and revised the article. Zhimeng Zhao helped with the experiment and provided suggestions for data analysis. Qiongfen Li and Shengchun Bi contributed to field data collection. All authors commented on the manuscript and approved the final version.

\section{Ethics approval}

Not applicable

\section{Consent to participate}

Not applicable

\section{Consent for publication}

Not applicable

\section{Acknowledgments}

We thank the Biogeochemistry Laboratory at Xishuangbanna Tropical Botanical Garden for conducting the chemical tests. The National Key Research and Development Program (2016YFC0502503) and the National Natural Science Foundation of China (41671031) supported this study. 


\section{References}

1. Clements R, Sodhi NS, Schilthuizen M et al (2006) Limestone karsts of Southeast Asia: imperiled arks of biodiversity. Bioscience 56:733-742. https://doi.org/10.1641/00063568(2006)56[733:LKOSAI]2.0.C0;2

2. Danielson RE, Sutherland PL (1986) Porosity. In: Klute A (ed) Methods of soil analysis. Part I. Physical and mineralogical methods. ASA and SSSA, Madison, pp 443-461

3. Du SG, Ge JR (1999) The new measuring method of joint roughness coefficients. Journal of Xi'an Highway University 2:10-13. (in Chinese with English Abstract)

4. Ford D, Williams PD (2013) Karst hydrogeology and geomorphology. John Wiley \& Sons, Chichester

5. Friedmann H, Beecher WJ (1942) Nesting birds and the vegetation substrate. Am Midl Nat 28:269. https://doi.org/10.2307/2420704

6. Göransson H, Edwards PJ, Perreijn K et al (2014) Rocks create nitrogen hotspots and N:P heterogeneity by funnelling rain. Biogeochemistry 121:329-338. https://doi.org/10.1007/s10533014-0031-x

7. Jiang ZC, Lian YQ, Qin XQ (2014) Rocky desertification in Southwest China: impacts, causes, and restoration. Earth Sci Rev 132:1-12. https://doi.org/10.1016/j.earscirev.2014.01.005

8. Li S, Ren HD, Xue L et al (2014) Influence of bare rocks on surrounding soil moisture in the karst rocky desertification regions under drought conditions. Catena (Amst) 116:157-162. http://dx.doi.org/10.1016/j.catena.2013.12.013

9. Liu HY, Dai JY, Xu CY et al (2020) Bedrock-associated belowground and aboveground interactions and their implications for vegetation restoration in the karst critical zone of subtropical Southwest China. Prog Phys Geogr 45:030913332094986. https://doi.org/10.1177/0309133320949865

10. Peng XD, Dai QH, Ding GJ et al (2019) Role of underground leakage in soil, water and nutrient loss from a rock-mantled slope in the Karst Rocky Desertification Area. J Hydrol (Amst) 578:124086. https://doi.org/10.1016/j.jhydrol.2019.124086

11. Sebela S, Slabe T, Liu H et al (2004) Speleogenesis of selected caves beneath the Lunan Shilin and caves of Fenglin karst in Qiubei, Yunnan. Acta Geol Sin-Engl 78:1289-1298. https://doi.org/10.1111/j.1755-6724.2004.tb00786.x

12. Shen YX, Huang J, Yang GR (2011) Comparison of tree sprouting in three regeneration stages of an evergreen broadleaved forest in a karst landscape, SW China. Acta Ecol Sin 31:126-131. (in Chinese with English Abstract)

13. Shen YX, Wang DJ, Chen QQ et al (2019) Large heterogeneity of water and nutrient supply derived from runoff of nearby rock outcrops in karst ecosystems in SW China. Catena (Amst) 172:125-131. https://doi.org/10.1016/j.catena.2018.08.020

14. Smets T, Lopez-Vicente M, Poesen J et al (2011) Impact of subsurface rock fragments on runoff and interrill soil loss from cultivated soils. Earth Surf Process Landf 36:1929-1937.

https://doi.org/10.1002/esp.2220 
15. State Forestry of China (2012) Rock desertification in karst area, China. http://www.forestry.gov.cn/uploadfile/main/2012-6/file/2012-6-15147e8ffa780643d68d6126b67ae60d7b.pdf

16. Tetegan MN, Korboulewsky A, Bouthier A, Samouelian et al (2015) The role of pebbles in the water dynamics of a stony soil cultivated with young poplars. Plant Soil 391:307-320. https://doi.org/10.1016/j.jappgeo.2005.06.003

17. Vanak AT, Thaker M, Slotow R (2010) Do fences create an edge-effect on the movement patterns of a highly mobile mega-herbivore? Biol Conserv 143:2631-2637. https://doi.org/10.1016/j.biocon.2010.07.005

18. Viles H (1995) Ecological perspectives on rock surface weathering: towards a conceptual model. Geomorphology 13:21-35. https://doi.org/10.1016/0169-555X(95)00024-Y

19. Waele JD, Gutiérrez F, Parise M et al (2011) Geomorphology and natural hazards in karst areas: a review. Geomorphology 134:1-8. https://doi.org/10.1016/j.geomorph.2011.08.001

20. Wang DJ, Shen YX, Huang J et al (2016) Rock outcrops redistribute water to nearby soil patches in karst landscapes. Environ Sci Pollut R 23:8610-8616. https://doi.org/10.1007/s11356-016-6091-9

21. Wang DJ, Shen YX, Li YH et al (2016) Rock outcrops redistribute organic carbon and nutrients to nearby soil patches in three karst ecosystems in SW China. PLoS One 11:e0160773. https://doi.org/10.1371/journal.pone.0160773

22. Wang RS, Ma SJ (1985) Edge effect and its application in economic ecology. Chin J Ecol 2:38-42. (in Chinese with English Abstract)

23. Yan Y, Dai Q, Jin L et al (2019) Geometric morphology and soil properties of shallow karst fissures in an area of karst rocky desertification in SW China. Catena (Amst) 174:48-58.

https://doi.org/10.1016/j.catena.2018.10.042

24. Zhang YH, Zhang MX, Niu JZ et al (2016) Rock fragments and soil hydrological processes: significance and progress. Catena (Amst) 147:153-166. https://doi.org/10.1016/j.catena.2016.07.012

25. Zhao ZM, Shen YX, Jiang RH et al (2020) Rock outcrops change infiltrability and water flow behavior in a karst soil. Vadose Zone J 19:e10002. https://doi.org/10.1002/vzj2.20002

26. Zhu XA, Shen YX, He BB et al (2017) Humus soil as a critical driver of flora conversion on karst rock outcrops. Sci Rep 7:12611. https://doi.org/10.1038/s41598-017-13060-5

\section{Figures}




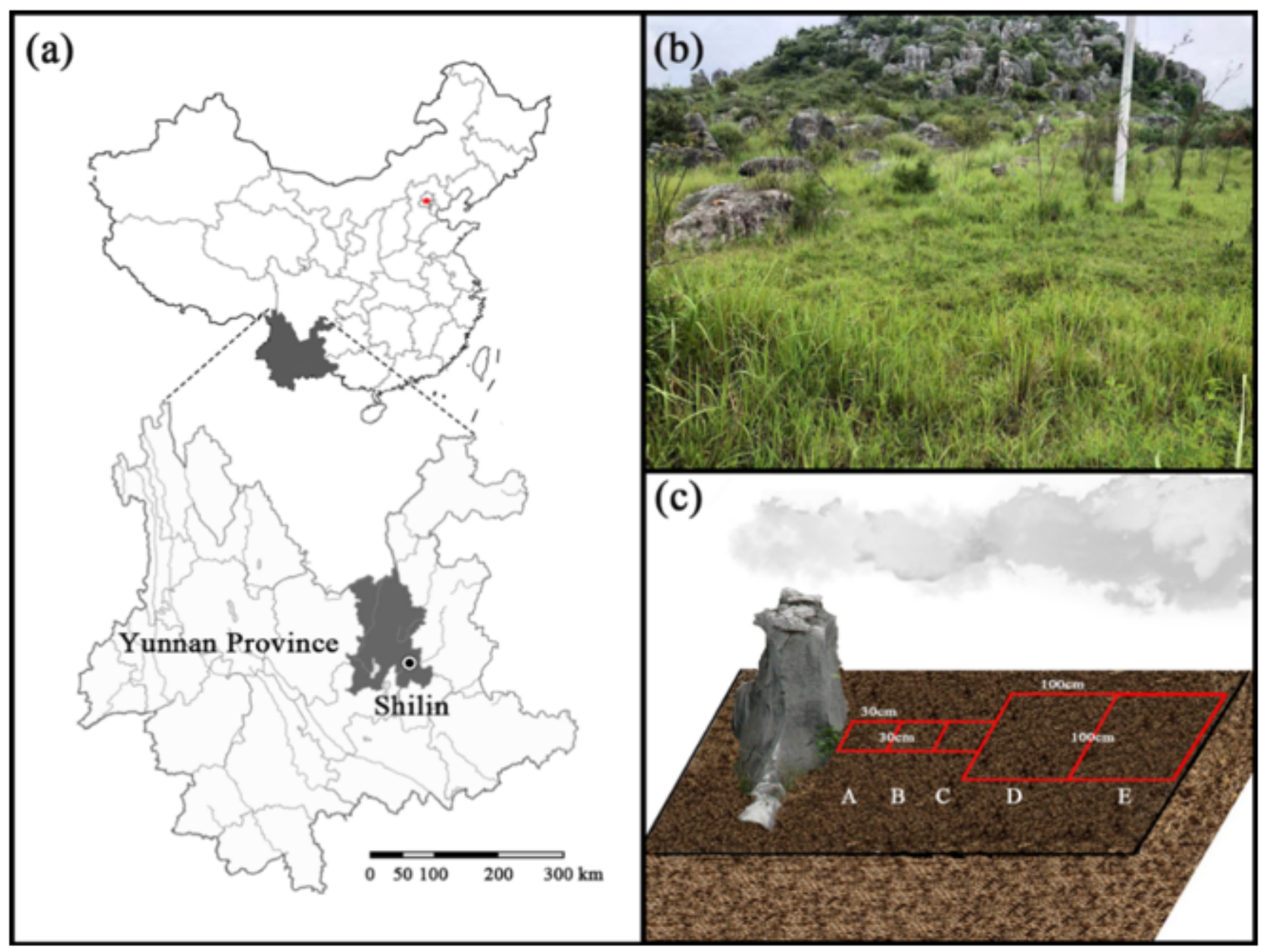

\section{Figure 1}

(a) Location of the study site in Yunnan Province, SW China, (b) karst grassland site with emerging rock outcrops, and (c) schematic of the five areas sampled for soil properties and plant biomass Note: The designations employed and the presentation of the material on this map do not imply the expression of any opinion whatsoever on the part of Research Square concerning the legal status of any country, territory, city or area or of its authorities, or concerning the delimitation of its frontiers or boundaries. This map has been provided by the authors. 
(a) Aboveground biomass

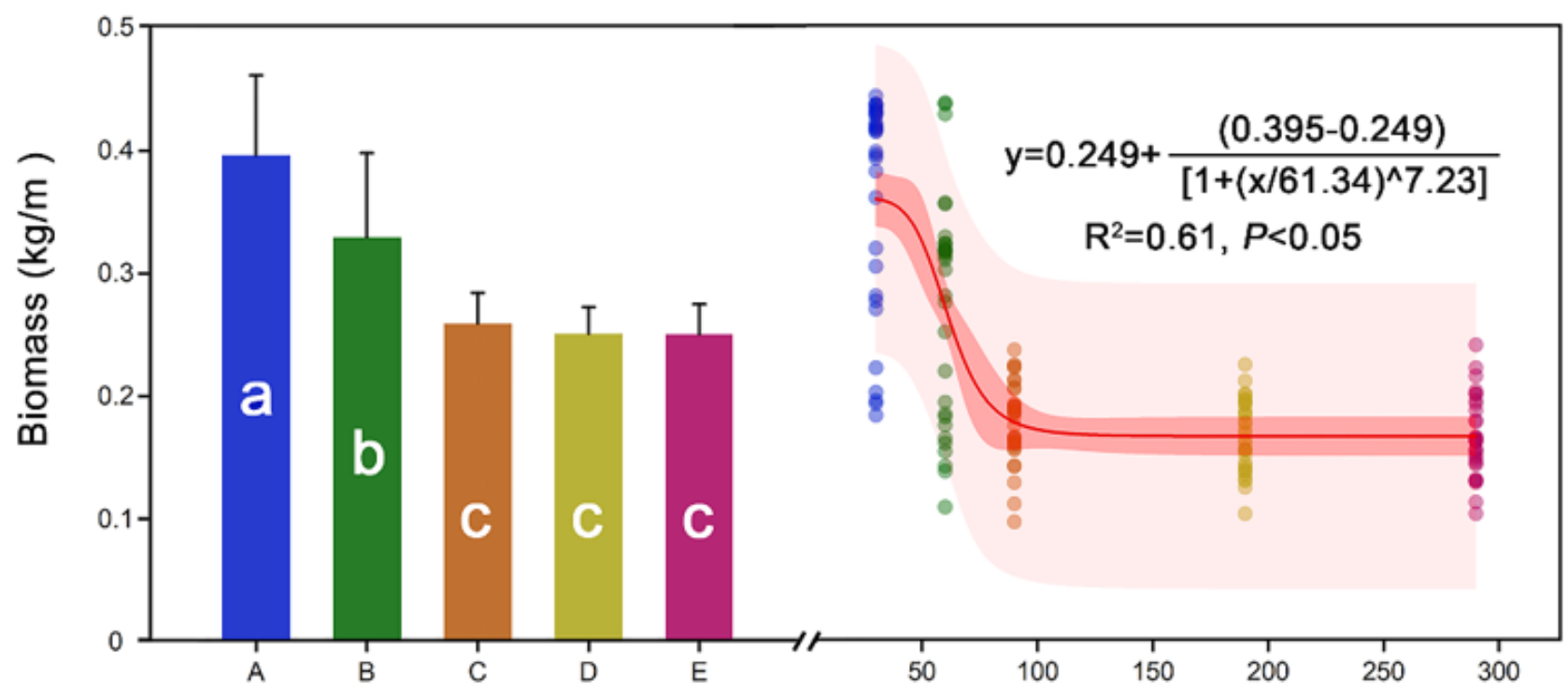

(b) Belowground biomass

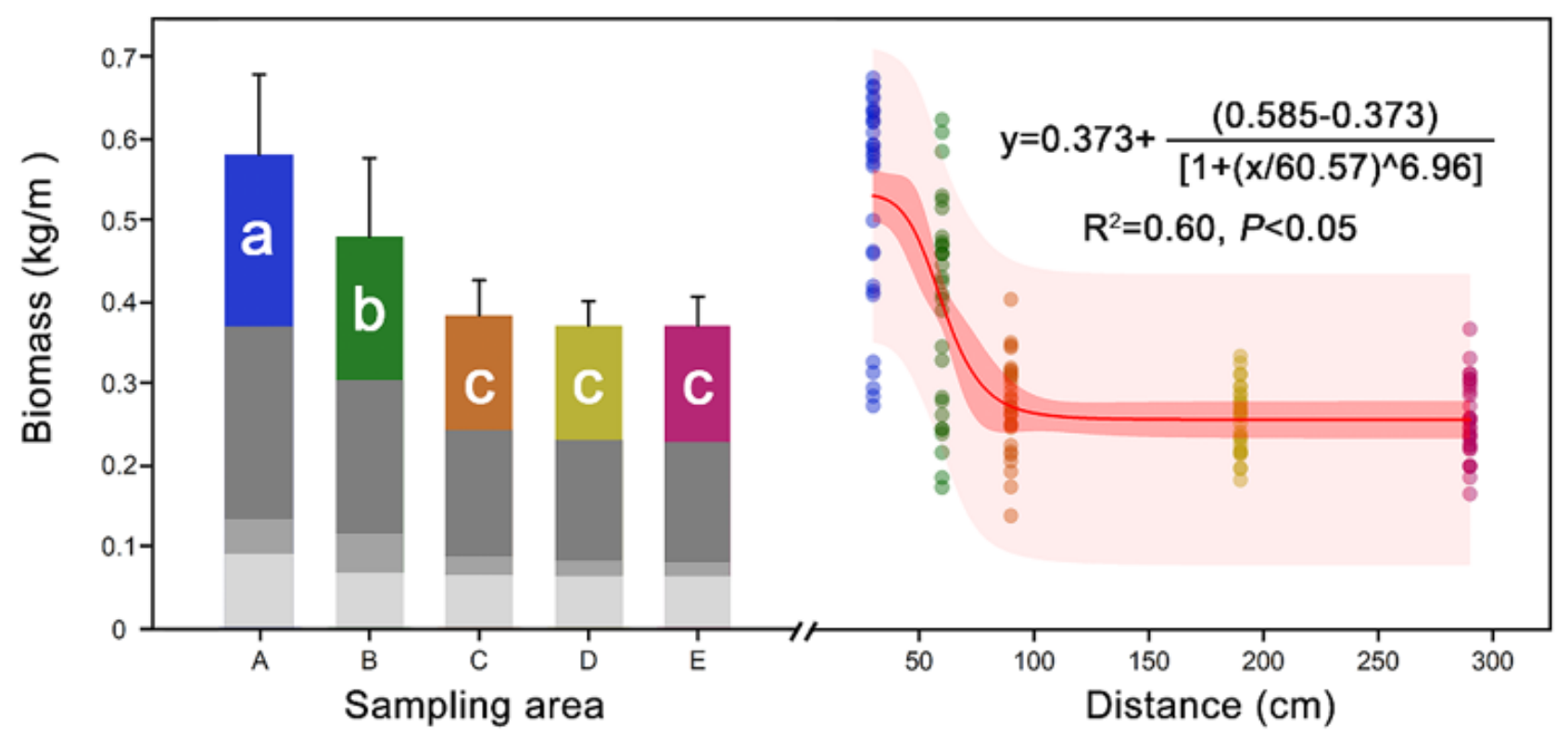

Figure 2

Variation in (a) aboveground and (b) belowground biomass in each sampling area, and the fitted equations between biomass and distance to ROCs. Distances of sampling areas from the base of rock outcrops: A, 0 to $30 \mathrm{~cm} ; \mathrm{B}, 31$ to $60 \mathrm{~cm}$, C, 61 to $90 \mathrm{~cm} ; \mathrm{D}, 91$ to $190 \mathrm{~cm} ; \mathrm{E}, 191$ to $290 \mathrm{~cm}$. Different lowercase letters within the bars indicate significant differences among sampling areas $(P<0.05)$ 

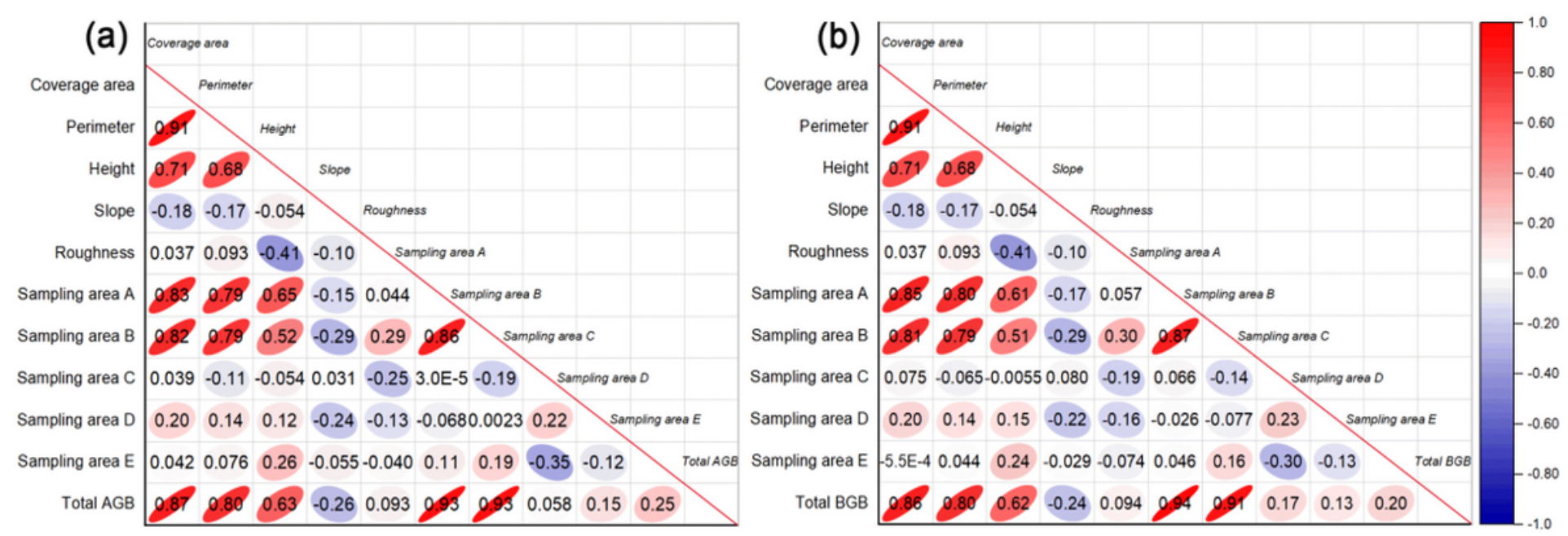

\section{Figure 3}

Correlations between morphological parameters of rock outcrops (ROCs) and the biomass of herbs. Correlation coefficient matrix between morphological parameters of the ROCs and (a) aboveground biomass (AGB) and (b) belowground biomass (BGB). The numbers in the diagrams are correlation coefficients ( $r$, Pearson correlation test; $P<0.05)$. Distances of sampling areas from the base of rock outcrops: A, 0 to $30 \mathrm{~cm}$;, 31 to $60 \mathrm{~cm}$;, 61 to $90 \mathrm{~cm}$;, 91 to $190 \mathrm{~cm} ; \mathrm{E}, 191$ to $290 \mathrm{~cm}$

(a) Aboveground biomass

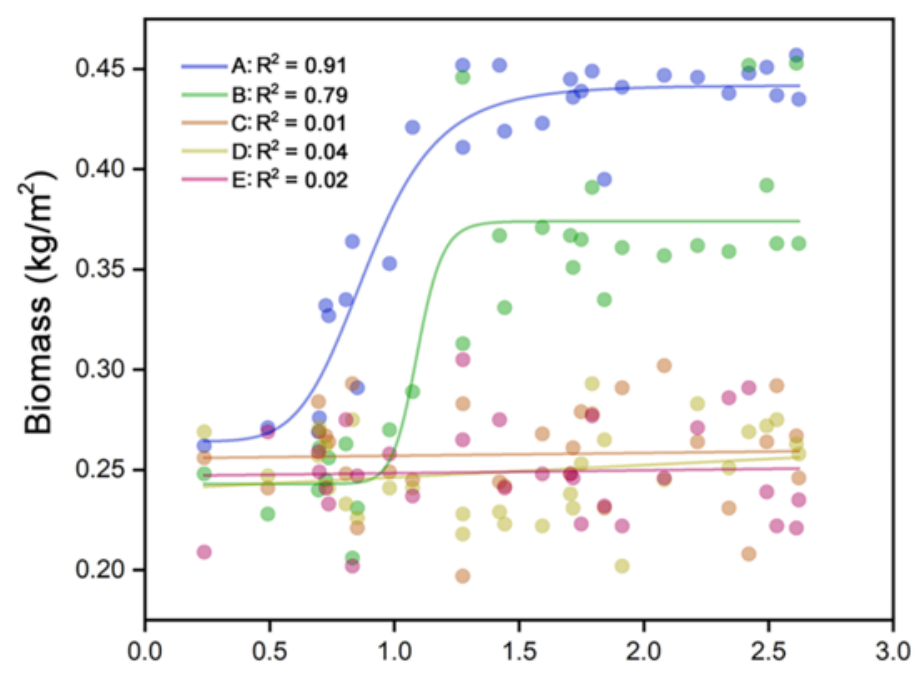

(b) Belowground biomass

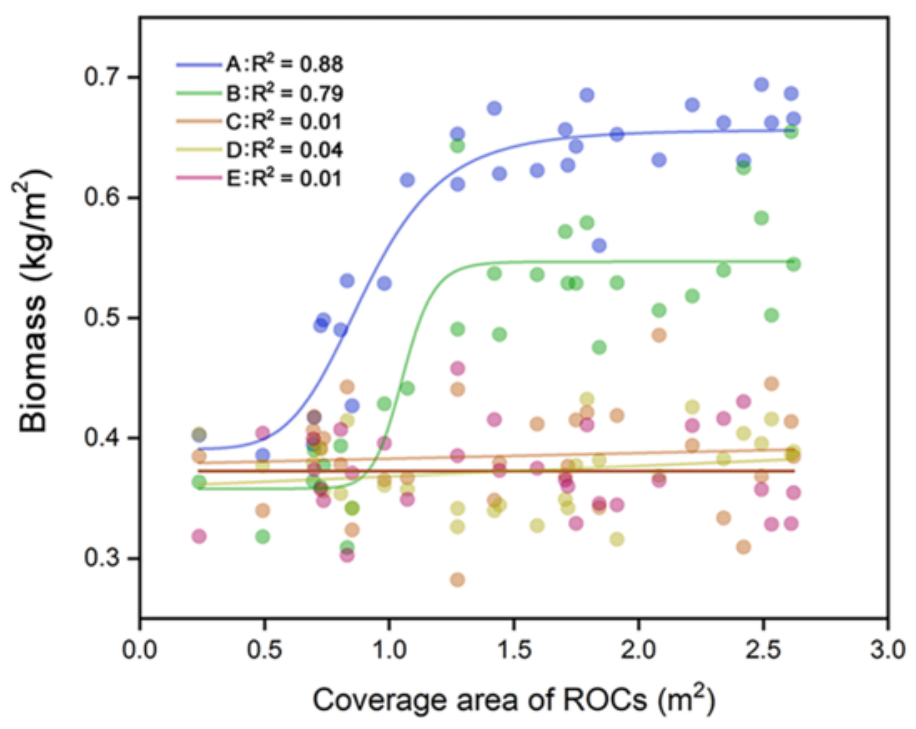

\section{Figure 4}

Regressions between the coverage area of rock outcrops (ROCs) and plant (a) aboveground biomass and (b) belowground biomass. In sampling areas $A$ and $B$, logistic regression was used $(P<0.05)$; in sampling areas $C, D$, and $E$, linear regression was used. Distances of sampling areas from the base of rock outcrops: A, 0 to $30 \mathrm{~cm} ; \mathrm{B}, 31$ to $60 \mathrm{~cm} ; \mathrm{C}, 61$ to $90 \mathrm{~cm}$;, 91 to $190 \mathrm{~cm} ; \mathrm{E}, 191$ to $290 \mathrm{~cm}$ 